This PDF is a selection from a published volume from the National Bureau of Economic Research

Volume Title: Innovation Policy and the Economy, Volume 2

Volume Author/Editor: Adam B. Jaffe, Josh Lerner and Scott Stern, editors

Volume Publisher: MIT Press

Volume ISBN: 0-262-60045-5

Volume URL: http://www.nber.org/books/jaff02-1

Conference Date: April 17, 2001

Publication Date: January 2002

Title: Do We Have a "New" Macroeconomy?

Author: J. Bradford DeLong

URL: http://www.nber.org/chapters/c10788 


\title{
Do We Have a "New" Macroeconomy?
}

\author{
J. Bradford DeLong, University of California, Berkeley
}

\section{Executive Summary}

Claims that we are in a "new economy" have become less strident over the past year with the collapse of Internet-company stock valuations. Nevertheless, the smart way to bet is that the data processing and data communications revolutions have significantly altered and will continue to alter the structure of the macroeconomy and the pattern of the business cycle. The informationtechnology revolution is the prime candidate for driving the acceleration in aggregate labor productivity growth in the 1990s, and the boom in information-technology investment promises to pay dividends in the form of accelerated aggregate labor productivity growth for at least a decade to come. It is a credible candidate for driving the reduction in the natural rate of unemployment (the NAIRU). It may well promise to diminish the aggregate economy's vulnerability to inventory fluctuations, which have for more than a century been a principal driving force behind the business cycle.

\section{Introduction}

Claims that we are in a "new economy" are less strident than a year ago. The crash of the technology-heavy NASDAQ market (figure 5.1), the end of the tech-heavy IPO boom, and the inability of investment analysts today to recall why they placed such high valuations on technology leaders only a few months ago ${ }^{1}$ have silenced voices that used to claim that the old economic rules had been superseded. Odds are that enthusiasm for the "new economy" will cool still more, for the stock market appears to have further to fall. ${ }^{2}$

But just as the conventional wisdom over much of the past half decade was irrationally exuberant, so current opinion is in danger of becoming overpessimistic. That the U.S. economy is in danger of falling into recession, that unemployment rates are likely to rise throughout 2000 and perhaps beyond, that the stock market sometimes fluctuates 


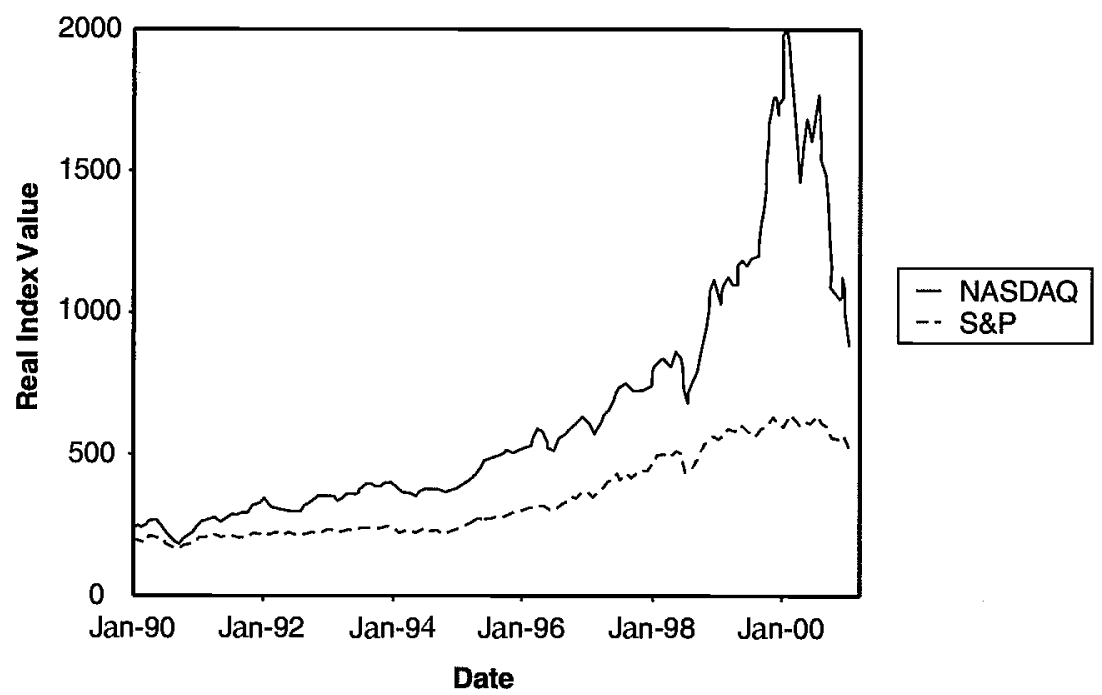

Figure 5.1

Real values of S\&P500 and NASDAQ stock market indices.

downward as well as upward-these facts are not relevant to the important and interesting structural issues. As I wrote two years ago, the new economy is "not about ... smooth growth, permanently rising stock prices ... or permanently low rates of unemployment, interest and inflation." ${ }^{3}$ Instead, the new economy is about whether the ongoing technological revolutions are doing for information processing and organizational control something like what the technological revolutions of the nineteenth-century industrial revolution did for materials processing and transportation. ${ }^{4}$

Are these ongoing technological revolutions powerful enough for us to see their impact on the macroeconomy - the patterns of trends and fluctuations exhibited by aggregate indicators like real GDP, the unemployment rate, inflation, and so forth? The smart way to bet is "yes." It seems likely-although not yet certain-that the data processing and data communications revolutions have significantly altered and will continue to alter the structure of the macroeconomy and pattern of the business cycle. Specifically:

- The information technology revolution has almost surely driven the recent acceleration in American productivity growth, and there is good reason to believe that productivity growth will continue at its current, higher rate for at least a decade. 
- A likely important macroeconomic consequence of the acceleration in productivity growth is the improved labor market and reduced natural rate of unemployment (NAIRU) that we are seeing today. The high-pressure economy, tight labor market, and gratifyingly low unemployment rate are hard to envision without the productivity speedup, which is largely driven by the technological revolutions in data processing and data communications.

- A possible macroeconomic consequence of the computerization of American business is a decline in the inventory-fluctuation-driven component of the business cycle. Already the decline in aggregate inventory-to-shipments ratios in manufacturing is substantial. However, we have not yet seen whether theoretical predictions that a leaner inventory chain means a smaller business cycle come true.

- Another possible macroeconomic consequence is increased financial market volatility, which would take the form of both a faster and more complete response of financial markets to news and a faster and more exaggerated response of financial markets to noise. This is worth worrying about because of its potential significance for the making of economic policy. But as of yet we have no real data with which to assess this possibility.

This paper attempts to provide interested readers with a roadmap to guide them through the issues involved in thinking about our modern technological revolutions, structural change, and macroeconomic performance. After this first, introductory section, section II steps back and provides a historical perspective on technological revolutions, structural change, and macroeconomic performance-the main point of which is that in the past it has been remarkably difficult to draw clear links between the first two and the third. Section III summarizes the now near-complete consensus that the acceleration in measured productivity growth in the U.S. in the mid-1990s is due primarily to information technology; it further argues that these technologies have been diffusing through the economy sufficiently slowly that we should see measured trend productivity grow at its current, accelerated rates for a decade or more; and it speculates about the relationship between measured and true productivity growth.

Section IV turns to the fall in the NAIRU-the natural rate of unemployment, the unemployment rate consistent with stable inflation. There is by now good reason to tentatively conclude that the NAIRU has stronger links with the overall rate of productivity growth than 
previously thought; if so, then the good performance of the labor market in the 1990s is due, indirectly, to the revolution in information technology working through the rate of productivity growth.

Section $V$ notes the fall in inventories that has taken place over the past two decades as information technology has spread through American businesses, and speculates that the large component of the business cycle that has been driven by errors in forecasting and inventory pile-ups will diminish.

But not everything that is good about the macroeconomy is due to information technology. And not everything that is due to information technology that affects the macroeconomy is good. Section VI points out that financial markets that appear more unstable may well also be a result of the "new economy."

Section VII provides a very brief conclusion.

\section{Structural Change and Macroeconomic Performance}

The past hundred and fifty years have seen the world's advanced industrial economies shift from primarily agricultural to primarily industrial and now primarily service economies. They have seen repeated technological revolutions, as one leading sector after another-chemicals, electricity, autos, aircraft-has taken the lead in productivity acceleration. They have seen the rise of sophisticated systems of consumer credit that allow households to smooth their spending over time. They have seen the rise of the modern social insurance state to serve as a sea-anchor for the economy by virtue of the large relative size of its spending programs. They have seen the rise of systems of deposit insurance to reduce the probability of a massive chain of bankruptcies and thus a full-fledged financial panic. They have seen the government take on responsibility for managing the macroeconomy.

Yet in spite of all these structural changes, the American business cycle in the second half of the twentieth century has looked remarkably like the American business cycle in the last quarter of the nineteenth century. Arthur Burns (1960) could confidently predict that better macroeconomic policy and structural change meant that "the business cycle is unlikely to be as troubling or disturbing to our children as it once was to our fathers. ${ }^{\prime 5}$ But the best available evidence is that Burns was more wrong than right. We hope that better macroeconomic policy has eliminated the risk of another Great Depression. ${ }^{6}$ But it is very 
difficult to show convincingly any significant reduction in the size of the business cycle on comparing the pre-Depression with the postWorld War II period.

Table 5.1 reports Romer's (1999) estimates of business-cycle volatility as estimated by the standard deviation of the annual percentage change in consistent estimates of four key macroeconomic variables: industrial production, real GDP, commodity production, and the percentage-point change in the unemployment rate. The effect of the Great Depression in making business cycles during the 1920-1940 interwar period far larger than in either of the other two is clear. It is also clear that these point estimates of volatility are higher before World War I: $27 \%$ higher for unemployment, $24 \%$ higher for industrial production, $20 \%$ higher for real GDP, and $6 \%$ higher for commodity production. But the degree of stabilization is small, especially considering the magnitude of structural change.

Even though the business cycle has been almost as volatile since World War II as before World War I, its pattern has undergone some changes. Back before World War I the average business-cycle expansion lasted less than three years. Since World War II it has lasted more than four and a half years, as table 5.2 shows.

Why have expansions been longer in recent years? Romer attributes this-I believe correctly-to successful management shocks by the Federal Reserve, which has managed to smooth out and counteract downward disturbances to demand that would have generated recessions in previous years.

Why has the business cycle not been less volatile if the Federal Reserve has successfully leaned against the prevailing economic wind? Because even though it has successfully damped some disturbances, the Federal Reserve itself has caused other disturbances. Most post-World War II recessions have arisen because the Federal Reserve has concluded that it is time to fight inflation even at the risk of a recession. Back before World War I such inflation-control recessions were nonexistent.

The bottom line is that the business cycle has been with us for a very long time, in spite of mammoth changes in economic structure and in technology. The business cycles we experience today are still very close in structure and development to those analyzed in Burns and Mitchell (1946), or indeed in Juglar (1916). So we cannot anticipate that any technological revolution would overthrow all of macroeconomics. The new macroeconomy will be like the old in structure, with the principal 
Table 5.1

Standard deviations of annual changes in macroeconomic variables

\begin{tabular}{lccc}
\hline & \multicolumn{3}{c}{ Standard deviation (\%) } \\
\cline { 2 - 4 } Variable & $1886-1916$ & $1920-1940$ & $1948-1997$ \\
\hline Industrial production & 6.2 & 16.0 & 5.0 \\
Real GDP & 3.0 & 7.1 & 2.5 \\
Commodity production & 5.2 & 9.0 & 4.9 \\
Unemployment & 1.4 & NA & 1.1 \\
\hline
\end{tabular}

Source: Romer (1999).

effects seen in the relative importance of different factors and the relative size of summary parameter values.

\section{The Sharp Acceleration in Productivity Growth}

In the nonfarm business sector-the part of the economy on which productivity studies typically focus-output per labor hour rose between 1995 and 2000 at $2.5 \%$ per year, more than double the pace seen in the preceding quarter century since $1970 .{ }^{7}$ This acceleration of productivity growth raises for the first time in a generation the likelihood of reasonably rapid and broad-based real income growth, if the jump in productivity growth can be sustained. In the long run, productivity growth and average income growth must correspond. An era like that of 1970-1995 in which productivity growth is slow must be, in Paul Krugman's (1989) phrase, an "age of diminished expectations."

The case for attributing this acceleration in productivity growth to the technological revolutions in information technology is now very strong. If this attribution is correct, then this reacceleration of productivity growth is the most significant macroeconomic consequence of the "new economy," and one that all by itself justifies focusing much attention on computers and communications.

Back before 1995 critics of visionaries who saw the computer as transforming the world pointed to slow and anemic growth in aggregate labor productivity. The end of the 1960s saw the American economy undergo an aggregate productivity slowdown, in which the trend growth rate of labor productivity fell by more than half. It seemed unreasonable that what computer visionaries were touting as an extraordinary advance in technological capabilities should be accompanied by a record-breaking slowdown in economic growth. As Nobel Prizewinning MIT economist Robert Solow posed the question, if the 
Table 5.2

Average length of business-cycle phases

\begin{tabular}{lccc}
\hline & \multicolumn{3}{c}{ Average length (months) } \\
\cline { 2 - 4 } Phases & $1886-1916$ & $1920-1940$ & $1948-2000$ \\
\hline Recessions & 9.7 & 14.0 & 10.7 \\
Expansions & 34.0 & 31.6 & 55.9 \\
\hline
\end{tabular}

Source: Romer (1994), updated.

computer is so important, "how come we see the computer revolution everywhere but in the [aggregate] productivity statistics?"

After Solow's question, productivity performance worsened still further. In the decade and a half before Solow asked his question in 1987 output per hour grew at $1.1 \%$ per year. In the eight years after 1987 output per worker grew at only $0.8 \%$ per year.

This productivity paradox was sharpened because at the microeconomic level economists and business analysts had no problem finding that investments in high technology had enormous productivity benefits. MIT economist Erik Brynjolffson and his coauthors (Brynjolffson (1993), Brynjolffson and Hitt $(1996,2000)$, and Brynjolffson and Yang (1999)) found typical rates of return on investments in computers and networks of more than $50 \%$ per year. Firms that invested heavily in information technology and transformed their internal structures so that they could use their new technological capabilities flourished in the 1980s and 1990s-and their lagging competitors did not. ${ }^{8}$

However, as Federal Reserve Board economists Oliner and Sichel (1994) pointed out in the early 1990s, the then failure to see the computer revolution in the aggregate productivity statistics should not have come as a surprise. ${ }^{9}$ In the 1970s and 1980s the computer industry was simply too small a share of the economy and its output was not growing fast enough for it to have a large effect on aggregate productivity. According to their estimates, in the 1980s information technology capital-computer hardware, software, and communications equipment-accounted for $3.3 \%$ of the income earned in the economy, and the price-adjusted information technology capital stock was growing at only $14 \%$ per year. You multiply these two numbers together to get an estimate of the contribution of the information technology sector to economic growth: in this case, a contribution of $0.49 \%$ per year.

But beginning in 1992, the American economy began an extraordinary investment boom. From 1992 to 2000, real business fixed 
investment grew at $11 \%$ per year, with more than half of the additional investment going into computers and related equipment. And as the information technology investment boom took hold, productivity growth and growth in real GDP accelerated as well. Real GDP rose by an average of 3.9\% per year between 1995 and 2000. Nonfarm business measured labor productivity-measured output per hour workedgrew at $2.7 \%$ per year.

Initially some economists-most prominent among them Robert J. Gordon $^{10}$-doubted that the acceleration in labor productivity growth in the 1990s was anything more than an unsustainable cyclical phenomenon. Indeed, as figure 5.2 shows, labor productivity can exhibit large swings from year to year: the boom in productivity growth in 1992 was a flash in the pan (although it did give rise to a series of papers on the "jobless recovery"). The "morning in America" boom in productivity growth of 1983-1986 was also not sustained, at least in part because of high government budget deficits that reduced capital accumulation. What reason is there to believe that this boom in the second half of the 1990s is different?

The most powerful reason to believe that this acceleration of aggregate productivity growth is permanent, and not a flash in the pan, comes from the underlying growth accounting of the impact of the information technology revolution. Back in the 1980s information technology capital accounted for $3.3 \%$ of income earned in the economy; today, according to Oliner and Sichel (2000), it accounts for $7.0 \%$ of income earned. Back in the 1980s the economy's stock of information technology capital was growing at $14 \%$ per year; today, according to Oliner and Sichel (2000), it is growing at $20 \%$ per year. Multiply these two sets of numbers together to find that the increase in the economy's information technology capital stock was responsible for $0.5 \%$ per year of economic growth in the late 1980s, and for $1.4 \%$ per year of economic growth today. ${ }^{11}$

At this growth-accounting level of analysis, all of these factors are highly persistent. The rate of growth of the economy's information technology capital stock will not slow down rapidly or immediately. For one thing, the same number of dollars spent on computers or communication equipment today deliver perhaps three times as much in the way of real useful capital as they did five years ago because of the extraordinary fall in computer and communications equipment prices. ${ }^{12}$ Even simple use of amortization funds to replace obso- 


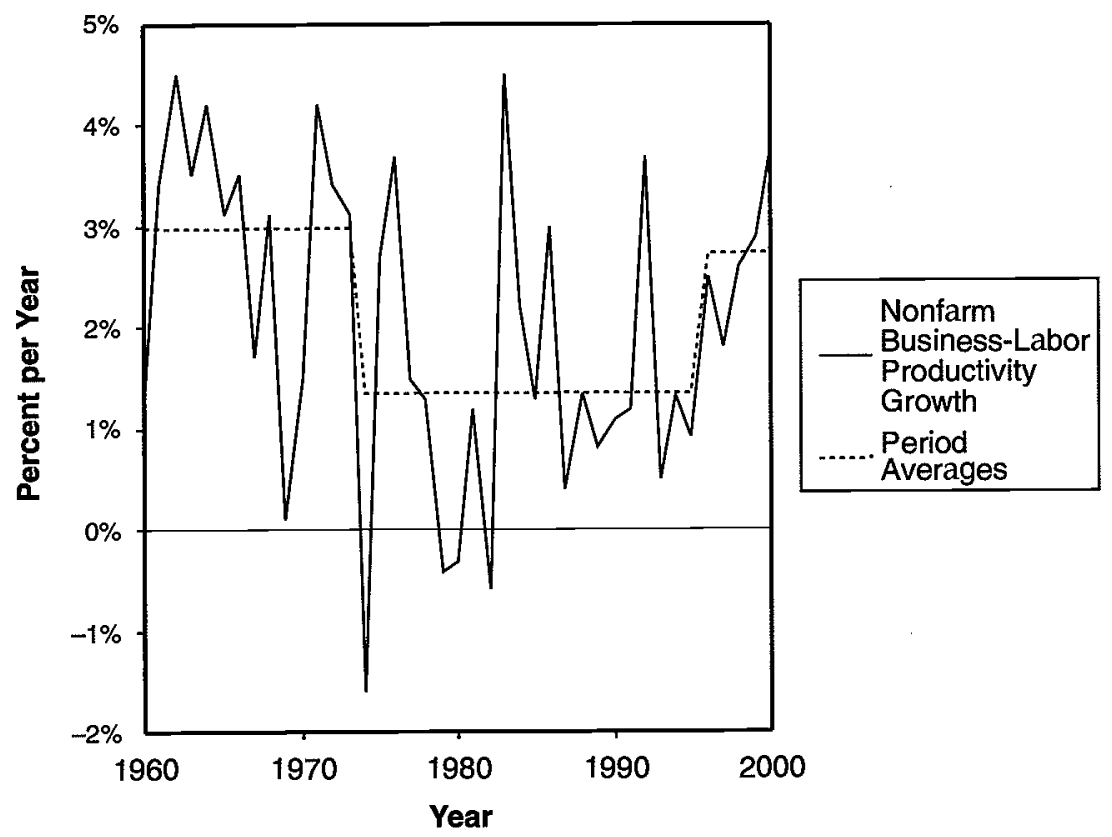

Figure 5.2

Annual labor productivity growth.

lete computers will generate enormous rates of increase in the capital stock.

Moreover, there is every reason to think that the fall in computer and communications equipment prices will continue. The pace of technological advance in information technology has been well described for three decades by what has come to be called Moore's law-the rule of thumb that Intel cofounder Gordon Moore set out a generation ago, that the density of circuits we can place on a chip of silicon doubles every eighteen months with little or no significant increase in cost. Moore's law has held for thirty years; it looks like it will hold for another ten at least. Moore's law means that today's computers have 66,000 times the processing power of the computers of 1975. It means that in ten years computers will be approximately 10 million times more powerful than those of 1975 at roughly constant cost. The installed base of information processing power has increased at least 1 millionfold since the end of the era of electromechanical calculators in the 1950s. Such extraordinary increases in productivity in data process- 
ing and data communications equipment manufacture have the potential to have a large impact on overall productivity growth, as long as the share of total income attributable to computer capital-the marginal product of this form of investment-does not collapse.

Will the share of total income attributable to computer capital collapse? Probably not. One might wonder whether rapid improvements in a particular branch of industry will rapidly run into diminishing returns. The first candlepower of light one can produce after dark-with a candle or an oil lamp steady enough to read by-is a really big deal. The ten-thousandth is not. Extraordinary productivity growth in the provision of lighting, according to Nordhaus (1997), has had only a limited impact on overall standards of living because the price of light fell much faster than the quantity of lighting rose. The share of total income attributable to computer capital will remain constant only if the productive value of the marginal computer declines no more rapidly in percentage terms than the total computer capital stock increases. In theory there is no reason that the productive value of the marginal computer might not decline very rapidly indeed, and the value of computer services fall faster than the stock of computer capital providing those services grows.

In practice this seems very unlikely to be the case. As John Zysman has pointed out, one thing that makes computers likely to fit Bresnahan and Trajtenberg's (1995) definition of a true engine of growth, a true general purpose technology, is that each sequential fall in the price of computers has been accompanied by an exponential increase in the demand for computers because it makes feasible a whole new set of capabilities and uses.

Consider: the first, very expensive computers produced tables useful for calculating artillery trajectories and were of use only to governments with special-purpose needs for intensive calculation. Back in those days the primary meaning of "computer" was someone who worked on the Manhattan Project performing repetitive calculations. It is in that age that we have Thomas Watson's declaration that the world demand for computers is surely less than ten.

The second generation of somewhat cheaper computers found a use not in making sophisticated calculations, but in making the extremely large number of simple calculations needed by the Census Department and by the human resource departments of large corporations. The third generation of computers was used to stuff data into and pull data out of databases in real time in airline reservations processing systems, 
insurance systems, and the like. Computers came to American business as word processors and what-if machines: devices to answer questions like "what if this paragraph looked like that?" or "what if the growth rate were twice as fast?" Now computers have become embedded into objects as sensors and controllers. And computers have become networked, for paralleling the revolution in data processing capacity has been a similar revolution in data communications capacity.

At each stage, the fall in the price of computers has been marked not by a modest but by an enormous expansion of the uses to which these machines are put. There is no reason to anticipate that this will change. And so there is no reason to look for a slowdown in the computer-driven component of productivity growth.

Left to one side so far have been all of the complicated and unresolved issues surrounding the measurement of output-things that lead economists like William Nordhaus to throw the construction, services, government, and finance, insurance, and real estate sectors of the economy overboard as far as productivity calculations are concerned, and to focus on the remaining sectors, which he calls "well-measured output." As Alan Blinder (2000) puts it, there are large chunks of the economy in which productivity growth is not well measured at all. Many of these chunks are ones in which we would expect computer investment to yield substantial gains. Are we measuring them all? The conclusion has to be "no": "retailing over the Internet may offer many benefits to consumers (examples: cheaper comparison shopping, 24-hour availability, no travel costs, etc.), but such gains will never be counted in GDP, and hence will never appear in the productivity statistics."13

\section{The Fall in the Natural Rate of Unemployment}

Back at the start of the 1990s most macroeconomists estimated that the economy's natural rate of unemployment was between $6.5 \%$ and $7.0 \%$. If unemployment fell below that level, it was argued, inflation would begin to accelerate. Thus a Federal Reserve that wished to avoid major recessions by maintaining the public's confidence in its lack of tolerance for inflation could not afford to let the unemployment rate fall below $6.5 \%$.

These estimates were based on long historical experience, summarized in figure 5.3, which shows the track of inflation and unemploy- 


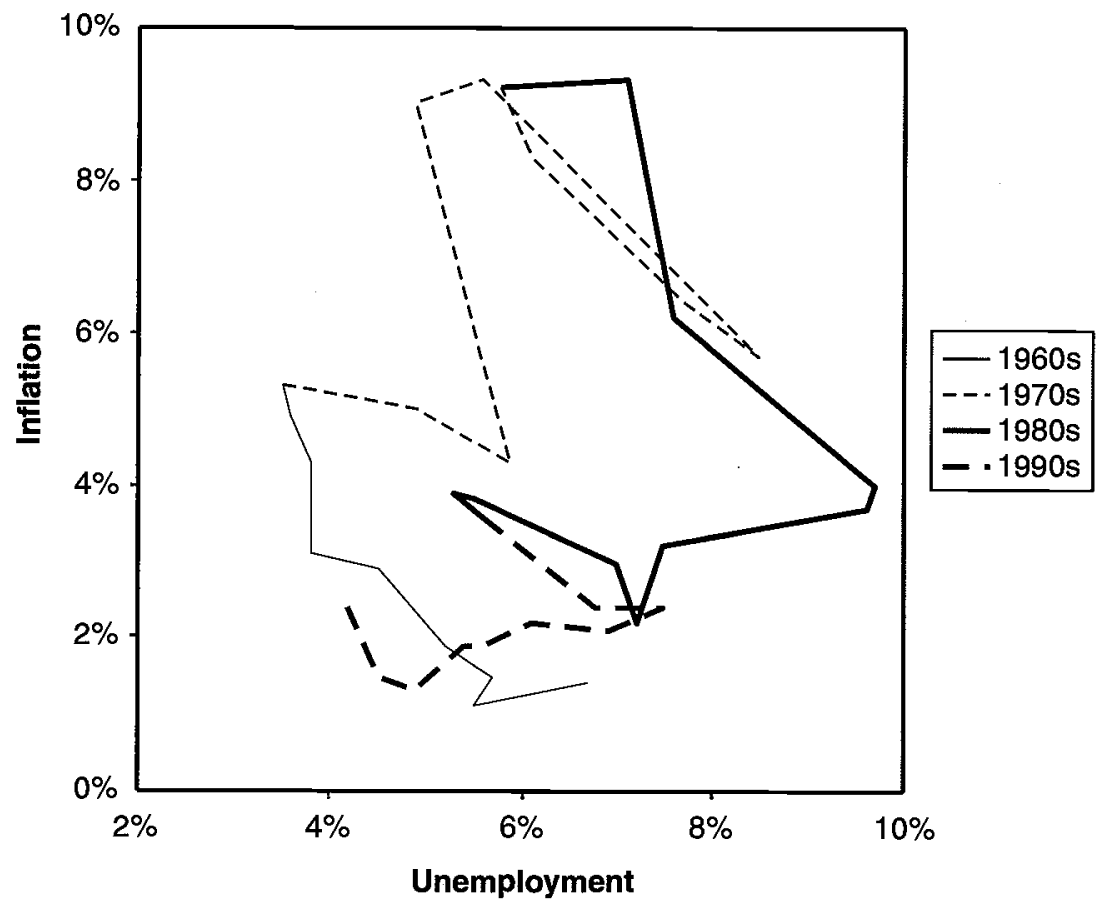

Figure 5:3

Inflation and unemployment.

ment in the U.S. economy since 1960. In the 1960s inflation increased when the unemployment rate fell below 5.5\%. In the early 1970s, it seemed as though inflation fell when the unemployment rate rose above $5.5 \%$, but then came the major accelerations in inflation produced by the oil price shock of 1973, and by the late 1970s it seemed as though it required an unemployment rate of $6.5 \%$ or more to put downward pressure on inflation.

In the 1980s, the workings of the labor market seemed worse: only when unemployment rose above $7 \%$ in the early 1980s did inflation fall noticeably. And in the late 1980s and early 1990s it seemed as though inflation rose whenever the unemployment rate fell below $6.5 \%$, and fell when the unemployment rate rose above $6.5 \% .^{14}$

Just about the time in the mid-1990s when the aggregate rate of productivity growth began to boom, the comovements of inflation and unemployment went off track. The fall in unemployment to $6 \%$ in the mid-1990s did not lead to any acceleration in inflation, nor did the fall in unemployment to $5 \%$ and then $4.5 \%$ in the late 1990 s. Only in the last 
year and a half or so, as the unemployment rate has fallen to $4 \%$, have there been any signs of rising inflation.

Macroeconomists call this particular set point of the economy-the rate of unemployment above which inflation tends to fall, and below which inflation tends to rise - the natural rate of unemployment, or alternatively (for those who wish to avoid the positive connotations carried by the word "natural") the NAIRU, an acronym for "non-accelerating-inflation rate of unemployment." In the early 1970s most macroeconomists thought the NAIRU was in the range of $5 \%$ to $5.5 \%$. By the early 1990s most macroeconomists thought it was in the range of $6 \%$ to $7 \%$. So nearly all macroeconomists have been surprised by the stunningly swift fall in the NAIRU down to somewhere in the neighborhood of $4.5 \%$ by the late $1990 \mathrm{~s}$.

By now the deviation between what inflation is and what one would have predicted inflation would be from the pre-1990s pattern is substantial. The most straightforward way to see the magnitude of the deviation is to take the simplest model for inflation-setting the change in the inflation rate to be a function of the lagged unemployment rate alone - and forecast what the current inflation rate would be if the unemployment rate had followed its historical path and if the previous pattern had continued to hold. As figure 5.4 shows, we would then expect the inflation rate this year to be nearly $6 \%$, instead of the $2.5 \%$ that the consensus forecast anticipates.

If the acceleration in productivity growth is the first, then this sharp fall in the NAIRU and sharp improvement in the economy's inflation-unemployment trade-off is the second major macroeconomic structural break seen in the 1990s. There is considerable confidence that the productivity growth acceleration could be traced to the revolutions in data processing and data communications. To what can we trace the fall in the NAIRU?

It is difficult to trace the fall in the NAIRU directly to "new economy" factors. It is simply not plausible to argue that online job searches have made the labor market's frictions less important. ${ }^{15}$ On the other hand, it is equally difficult to trace the fall in the NAIRU to demographic factors affecting the composition of the labor force or to changes in work organization. Demographic factors' plausible effects are an order of magnitude too small. And the timing is wrong to account for a large, sudden fall in the NAIRU in less than a decade. ${ }^{16}$

It is, however, possible that the natural rate of unemployment is linked to the rate of economy-wide productivity growth. The era of 


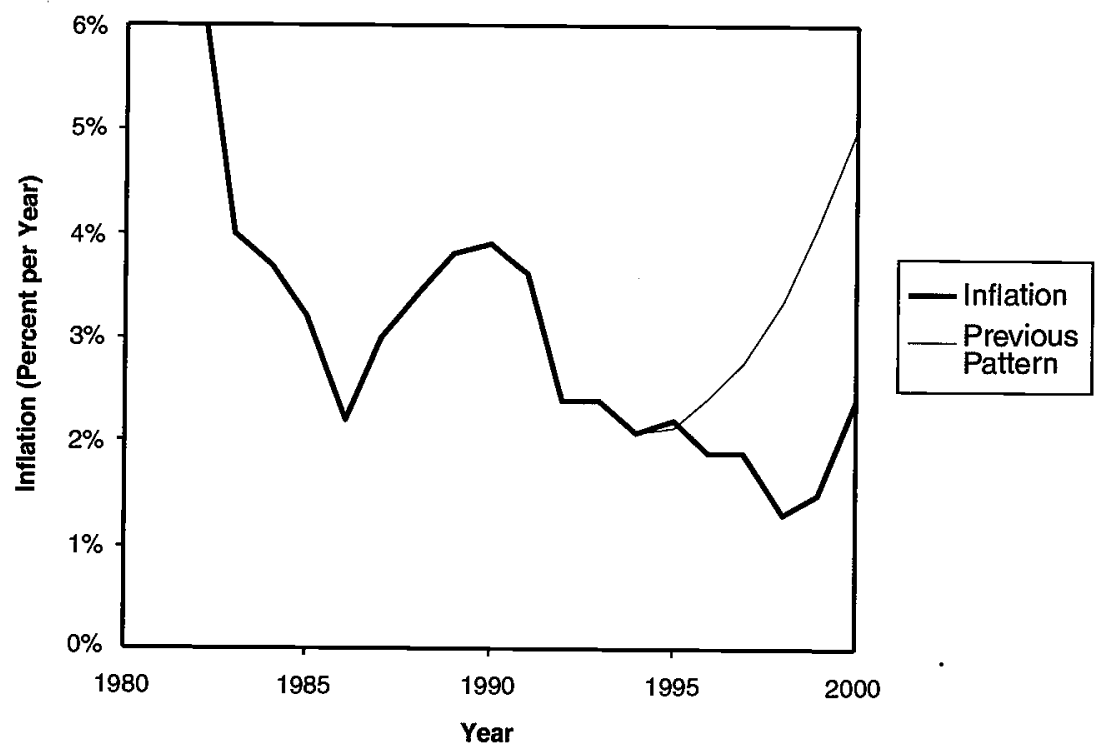

Figure 5.4

What if inflation since 1993 had followed its previous pattern?

slow productivity growth from the mid-1970s to the mid-1990s saw a relatively high natural rate. By contrast, rapid productivity growth before 1973 and after 1995 has been associated with a lower natural rate. If workers' aspirations for real wage growth themselves depend on the rate of unemployment and do not depend directly on productivity growth, then a speedup in productivity growth will reduce the natural rate.

If productivity growth is slow, then a low rate of unemployment will lead workers to demand high real wage increases-real wage increases above the rate of productivity growth. But firms cannot continuously grant real wage increases higher than the rate of productivity growth and still remain profitable. Long before their profits disappear, they will respond to the higher real wage growth aspirations and demands by economizing on workers. Unemployment will rise until the average unemployment rate is high enough to curb worker aspirations for real wage growth to a level consistent with trend productivity growth.

With a higher rate of productivity growth, firms can afford to pay higher real wage increases without going bankrupt. The unemployment rate consistent with real wage growth aspirations that match productivity is lower. Hence an economy with higher productivity growth has a lower natural rate of unemployment. 
There is no strong microeconomic evidence for this model in any form. Moreover, it does not meet modern macroeconomists' requirement that agents in models exhibit rational expectations. Workers whose real wage growth aspirations depend not on the rate of productivity growth but on the unemployment rate alone are myopic and irrational. But looking back over the past forty years, there is a remarkable qualitative fit between the high-productivity-growth, low-NAIRU 1960s and 1990s and the low-productivity-growth, high-NAIRU 1970s and 1980s.

The attribution of the fall in the NAIRU in the 1990s to the "new economy" - as an indirect consequence of the acceleration in productivity growth-is plausible and enticing, but far from proven.

\section{Manufacturing Inventories in the Economy}

To the extent that modern computer and communications technologies can be put to work as true information technologies, they will improve businesses' abilities to know about and manage their goods in the pipeline from initial raw materials to final sales. Individual firms will make fewer mistakes in forecasting demand for their own products, and in aggregate the total inventories in the economy will be less likely to unexpectedly accumulate or unexpectedly collapse in response to a mismatch between production and demand.

Managers claim that one of the principal benefits of new computer-and-communications technologies is better inventory control. Businesses today can control their inventories much more effectively. Interest and storage costs are lower. Stockouts are less frequent, and less costly.

This is potentially important for the size of the business cycle. As Blinder (1981) pointed out, in a typical recession the fall in inventory investment is between $50 \%$ and $100 \%$ of the peak-to-trough fall in real GDP. To a large extent, post-World War II recessions are episodes in which businesses have decided or have found that their inventories are too large, and have cut back drastically on production in order to liquidate some of these excess inventories. Significantly diminish the amplitude of aggregate mistakes in inventory accumulation, and you promise to significantly diminish the magnitude of fluctuations in aggregate demand, production, and employment as well.

It is in this context that it is interesting to note (figure 5.5) that the ratio of inventory to shipments in manufacturing has been on a steep decline for two decades, especially as far as durable manufacturing is 


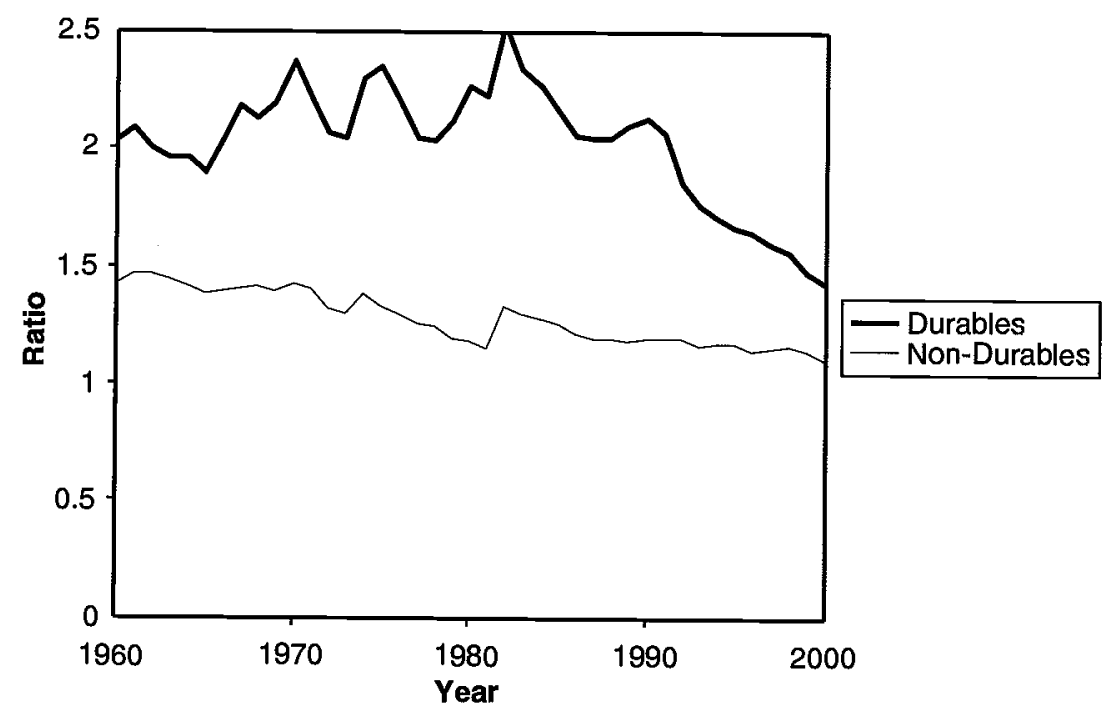

Figure 5.5

Inventory-to-shipments ratios in manufacturing.

concerned. Today's durable manufacturers hold only two-thirds as much inventory relative to their shipments as they held in the 1970s. Today's nondurable manufacturers hold one-fifth less inventory in proportion to sales than they did in the 1970s.

Now it would surely be a mistake to attribute all of this relative decline in inventories to the "new economy." Before there was a new economy, after all, there was a "Japanese challenge": American firms scrambled to develop and implement "lean production" systems that economized on inventories and achieved much greater control over materials flow and quality (see Womack 1991). But surely if information technologies are worthy of their name at all, they will improve business knowledge of what is going on inside the firm, and reduce the size of the inventory buffers needed to keep production running smoothly.

If the reduction in inventories made possible by modern information and communications technologies is close to reaching its limit, then we can expect that one consequence of the new economy is to moderate the inventory-driven portion of the business cycle. If the reduction in inventories has just begun-if improved information flow will truly make the new economy a just-in-time economy-then we can expect that the inventory-driven portion of the business cycle will be severely 


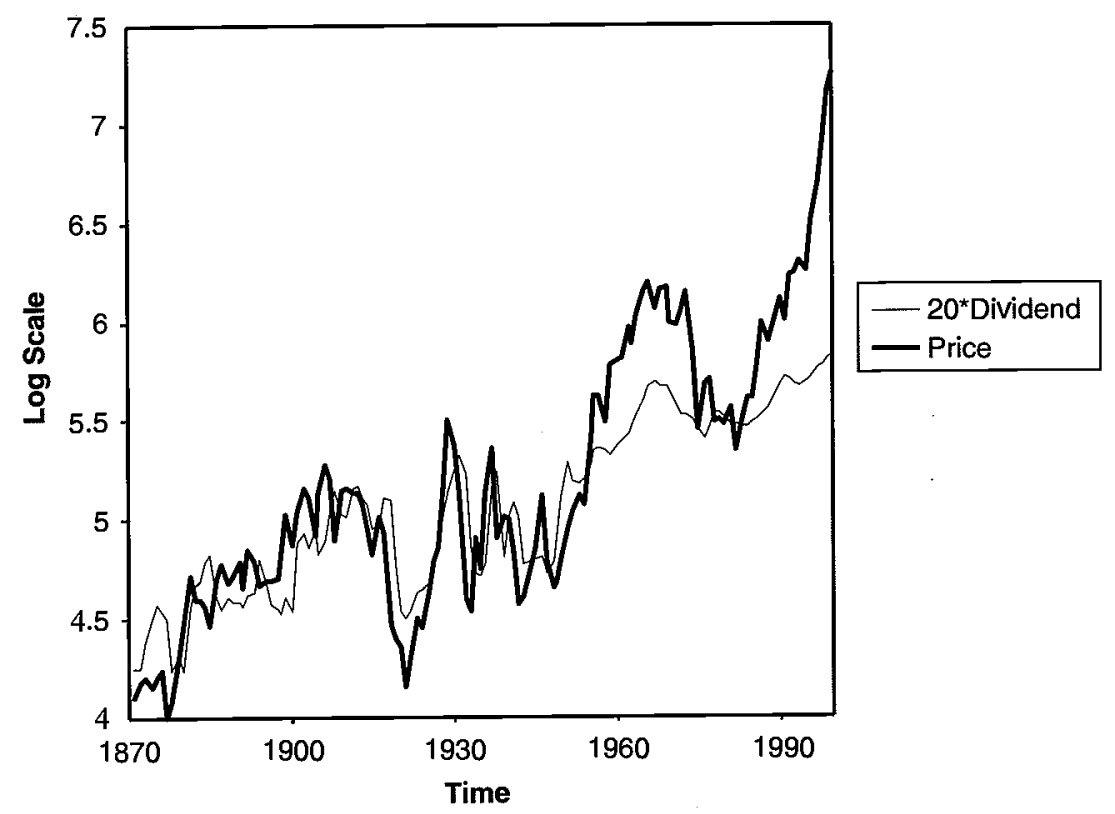

Figure 5.6

Real S\&P stock prices and dividends.

reduced. If Blinder's (1981) assessment of the importance of inventories remains true, this would be a significant gain in macroeconomic performance.

\section{Asset Markets}

If we look far back in history at the long bull runs of the American stock market-1890-1910, or 1920-1930, or 1950-1970-we see (figure 5.6) that for each $10 \%$ that the real value of dividends rise over a twenty-year period, the real value of stock prices tends to rise by $15 \%$. But if we look just at the most recent bull market-the one that started in 1982 -we find that a market-wide rise in dividends of $10 \%$ produces not a $15 \%$ but a $26 \%$ increase in stock prices. The runup in stock prices during the 1920s was extraordinary, but in real terms the increase in dividends paid out in the 1920s, and the increase in corporate profitability, was more than half of the increase in real stock market values. The runup in stock prices during the 1950s and 1960s was extraordinary too, but in real terms increases in dividends and in earnings were two-thirds as large as the increase in real values. 
The most recent bull market, as measured by the S\&P composite index, is the largest: a more than sevenfold increase in real values. Yet real dividends paid on a pro-rata share of the S\&P composite index have risen by less than $30 \%$ since the early 1980s. And earnings on a pro-rata share have increased by less than $50 \%$.

Any economist examining this pattern must reach one of two conclusions (or hedge his or her bets by taking a position between them). The first is that for a century the stock market has been grossly underpriced-has discounted the risk associated with owning equities at a much too high rate. It is only now that equity valuations are "fair" in the sense of promising expected real returns on stocks akin to those on bonds plus a small extra risk premium. The second is that the stock market today is subject to irrational exuberance on a scale never before seen in America. ${ }^{17}$

If the second conclusion is correct, what role has the "new economy" played in drawing tighter limits around the stabilizing potential of arbitrage $^{18}$ and in diminishing the information about fundamentals in the hands of the marginal investor? Barber and Odean (2001) point out that experimental economists have spelled out conditions under which markets are most vulnerable to prolonged mispricing and to speculative bubbles, and that our current stock market as it has been fueled by the growth of online trading and online information appears to meet all of them. Stock markets have managed to generate prolonged mispricing and spectacular crashes in the absence of the Internet in the past. But there is definitely reason to worry that the extra information about and access to the stock market provided by the information technology revolution has not led to a more informed marginal investor, or to a market that is a better judge of fundamental values.

\section{Conclusion}

Of the four principal shifts in the structure of the macroeconomy that we have examined here, we can be confident that the "new economy" is responsible for the first: the acceleration in productivity growth. We can also be confident that this acceleration in productivity growth is not going to evaporate quickly: the growth-accounting fundamentals that have led the technological revolution in data communications and data processing to boost aggregate productivity growth change only slowly. Moore's law is not going to vanish tomorrow. Nor is the economy about to run out of things for computers to do. 
The second shift-the sharp and sudden fall in the NAIRU-is less clearly attributable to the "new economy." There is no other plausible candidate to account for the swift reduction in the rate of unemployment consistent with stable inflation. But there is little direct evidence in favor of a link between faster productivity growth and a reduced NAIRU. And the models that predict such an association do not meet macroeconomists' requirement of rational expectations.

The third shift- the reduction in inventories-is driven by the information technology revolution as well as by other factors, and has been ongoing for a generation. How much of it is due directly to information technology is unknown. And we have not yet been able to see whether macroeconomic benefits in terms of reduced business cycle amplitude will follow from the leaner inventory pipeline that our economy is moving to.

The fourth shift-the bad shift, the increase in the volatility of the stock market-is in some sense completely due to the "new economy." With no belief in the new economy, there would have been no doubling of the NASDAQ index in four months-and no subsequent halving of the index in the year up to March 2001. The deeper question is whether our stock market works markedly worse as a social capital allocation mechanism now than it worked a generation ago because it has been corrupted by an unusual degree of speculative excess, and how much of this speculative excess is due to the information technology revolution. And for that question there is no answer.

\section{Notes}

I would like to thank U.C. Berkeley's Committee on Research for financial support, and Martin Baily, Stephen Cohen, Bob Cumby, Paul David, Michael Froomkin, Robert Gordon, Adam Jaffe, Robert Lipsey, Josh Lerner, Steve Oliner, Dan Sichel, Scott Stern, Lawrence Summers, Hal Varian, Robert Waldmann, Steve Weber, David Wilcox, Janet Yellen, and John Zysman for helpful discussions and comments. E-mail: delong@econ.berkeley.edu. URL: http://www.j-bradford-delong.net.

1. See Morgenson (2001).

2. See Shiller (2000). There is good reason to suspect that the inflow of investors into the market during the 1990s has made it more vulnerable and more volatile. See Barber and Odean (2001).

3. See Cohen, DeLong, and Zysman (2000).

4. See Landes (1969).

5. See also Delong and Summers (1986), whose confident belief that we could see the effects of structural change in the reduced size of the business cycle were fatally undermined by Romer (1994, 1999). 
6. Chiefly a better understanding of the circumstances under which fixed-exchange-rate systems like the gold standards can be destabilizing, fiscal automatic stabilizers to cushion the effects of a fall in income on demand, deposit insurance to serve as a firebreak to keep the system of financial intermediation from collapse, and a central bank that focuses enough attention on the money stock and does not make the false assumption that a low, safe, short, nominal interest rate means that credit is easy. On the other hand, anyone looking at the current situation of Japan must worry that even if economists know how to avoid deep depressions, politicians may not always listen to them.

7. Productivity growth starting in the early 1970s was anomalously and unexpectedly low-a phenomenon called the productivity slowdown. It is depressing to note that even now the causes of the productivity slowdown and of its persistence are not well understood. See Fischer (1988).

8. See Brynjolfsson and Hitt (1996); Brynjolfsson (1993).

9. An argument developed at greater length in Sichel (1997).

10. See Gordon (2000). At one level the differences between Gordon and the others are simply differences of emphasis: what is large enough for us to pay attention to? At another level, a key difference revolves around how one accounts for the effect of the business cycle, and what one would expect the effect of a fall in the natural rate of unemployment to be on potential output. According to Oliner and Sichel's growth-accounting model, a 2.5-percentage-point fall in the natural rate would boost potential output by the increase in employment times the share of income accruing to labor-a boost to potential output of perhaps $1.5 \%$. According to Gordon's more macro-oriented model, a 2.5percentage-point fall in the natural rate would boost potential output by the Okun's law coefficient of 2.5 times the change in the unemployment rate-a boost to potential output of $6.2 \%$. I come down on the side of the first approach, largely because I believe that the effect on potential output could not be as large as Okun's law suggests without generating markedly higher inflation, and we know that this decline in unemployment is associated with a fall in the natural rate and has not generated inflation. But it is not yet conclusively clear that Gordon's analysis is wrong.

11. Oliner and Sichel's conclusions are very similar to those of Jorgenson and Stiroh (2000). Both are backed up and strengthened in a very interesting series of papers by Hordhaus $(2000 a, 2000 b, 2001)$ that I have not yet had a chance to fully digest.

12. See Triplett (1999a, 1999b).

13. Many of these issues are addressed to some extent in Boskin et al. (1997).

14. For a more formal econometric analysis of the time-varying natural rate of unemployment - one that stresses the uncertainty surrounding our estimate of the natural rate at any moment in time- see Staiger, Stock, and Watson (1997).

15. See Autor (2001).

16. See Katz and Krueger (1999).

17. The conclusion reached by Robert Shiller (2000), who backs up his quantitative estimates of fundamental values with a great deal of thick description of the thought processes of market participants. Of course, only the thought processes of the marginal agent are truly relevant to assessing the information content of prices.

18. A way of thinking about the problem of noise trading developed by Shleifer and Vishny (1997). 


\section{References}

Autor, David. 2001. "Wiring the Labor Market." Journal of Economic Perspectives 15(1): 25-40.

Barber, Brad, and Terrance Odean. 2001. "The Internet and the Investor." Journal of Economic Perspectives 15(1): 41-54.

Blinder, Alan. 1981. "Inventories and the Structure of Macro Models." American Economic Review 71(2): 11-16.

Blinder, Alan. 2000. The Internet and the New Economy. Washington DC: Internet Policy Institute.

Boskin, Michael, Ellen Dulberger, Robert Gordon, Zvi Griliches, and Dale Jorgenson. 1997. "The CPI Commission: Findings and Recommendations." American Economic Review $87(2)$ : 78-83.

Bresnahan, Timothy F., and Manuel Trajtenberg. 1995. "General Purpose Technologies: 'Engines of Growth'?" Journal of Econometrics 65: 83-108.

Brynjolfsson, Erik. 1993. "The Productivity Paradox of Information Technology." Communications of the ACM 36(12): 67-77.

Brynjolfsson, Erik, and Shinkyu Yang. 1999. "The Intangible Costs and Benefits of Computer Investments: Evidence from the Financial Markets." Mimeo. Cambridge, MA: MIT.

Brynjolfsson, Erik, and L. Hitt. 1996, April. "Paradox Lost? Firm-Level Evidence on the Returns to Information Systems Spending." Management Science.

Brynjolfsson, Erik, and Lorin M. Hitt. 2000. "Beyond Computation: Information Technology, Organizational Transformation and Business Performance." Journal of Economic Perspectives 14(4).

Burns, Arthur F. 1960. "Progress Towards Economic Stability." American Economic Review 50(1): 1-19.

Burns, Arthur F., and Wesley C. Mitchell. 1946. Measuring Business Cycles. New York: National Bureau of Economic Research.

Cohen, Stephen, J. Bradford DeLong, and John Zysman. 2000. "Tools for Thought: What's New and Different About the E-conomy." Mimeo. Berkeley: University of California.

DeLong, J. Bradford, and Lawrence H. Summers. 1986. "The Changing Cyclical Variability of Economic Activity in the United States." In Robert J. Gordon, ed., The American Business Cycle: Continuity and Change. Chicago: University of Chicago Press: 679-734.

Fischer, Stanley. 1988. "Symposium on the Slowdown in Productivity Growth." Journal of Economic Perspectives 2(4): 3-7.

Gordon, Robert J. 2000. "Does the 'New Economy" Measure up to the Great Inventions of the Past?" Journal of Economic Perspectives 14(4).

Jorgenson, Dale, and Kevin Stiroh. 2000. "Raising the Speed Limit: U.S. Economic Growth in the Information Age." Brookings Papers on Economic Activity 2000(1): 125-211.

Juglar, Clement. 1916. A Brief History of Panics and Their Periodical Occurrence in the United States. New York: Augustus M. Kelley. 
Katz, Lawrence, and Alan Krueger. 1999. "The High-Pressure U.S. Labor Market of the 1990s." Brookings Papers on Economic Activity 1999(1): 1-65.

Krugman, Paul. 1989. The Age of Diminished Expectations. Cambridge, MA: MIT Press.

Landes, David. 1969. The Unbound Prometheus: Technological Change and Industrial Development in Western Europe from 1750 to the Present. Cambridge, U.K.: Cambridge University Press.

Morgenson, Gretchen. 2001, March 18. "How Did They Value Stocks? Count the Absurd Ways." New York Times.

Nordhaus, William D. 2000a. "Alternative Measures for Measuring Productivity Growth." Mimeo. New Haven: Yale University. <http://econ.yale.edu/ nordhaus/ homepage/writings_and_presentations_on_th.htm>.

Nordhaus, William D. 2000b. "Constructing Alternative Estimates of Output for Productivity Analysis." Mimeo. New Haven: Yale University. <http://econ.yale. edu/ nordhaus/homepage/writings_and_presentations_on_th.htm>.

Nordhaus, William D. 2001. "Productivity Growth and the New Economy." Working Paper no. 8096. Cambridge, MA: National Bureau of Economic Research. <http://www.nber.org/papers/w8096>.

Oliner, Stephen D., and Daniel E. Sichel. 1994. "Computers and Output Growth Revisited: How Big is the Puzzle?" Brookings Papers on Economic Activity 1994(2): 273-317.

Oliner, Stephen D., and Daniel E. Sichel. 2000. "The Resurgence of Growth in the Late 1990s: Is Information Technology the Story?" Journal of Economic Perspectives 14(4).

Romer, Christina D. 1994. "Remeasuring Business Cycles." Journal of Economic History 54(3): 573-609.

Romer, Christina. 1999. "Changes in Business Cycles: Evidence and Explanations." Journal of Economic Perspectives 13(2): 23-44.

Shiller, Robert. 2000. Irrational Exuberance. Princeton, NJ: Princeton University Press.

Shleifer, Andrei, and Robert Vishny. 1997. "The Limits of Arbitrage." Journal of Finance 52: 35-55.

Sichel, Daniel E. 1997. The Computer Revolution: An Economic Perspective. Washington DC: The Brookings Institution.

Staiger, Douglas, James H. Stock, and Mark W. Watson. 1997. "The NAIRU, Unemployment, and Monetary Policy." Journal of Economic Perspectives 11(1): 33-49.

Triplett, Jack. 1999a. "Computers and the Digital Economy." Washington DC: The Brookings Institution. <http://www.digitaleconomy.gov/powerpoint/triplett/sld001.htm>.

Triplett, Jack E. 1999b. "The Solow Computer Paradox: What Do Computers Do to Productivity?" Canadian Journal of Economics 32(2): 309-334.

Womack, James. 1991. The Machine that Changed the World. Cambridge, MA: The MIT International Motor Vehicle Program. Originally published by Rawson Associates, NY. 